\title{
CORTISONE THERAPY OF VISUAL LOSS IN TEMPORAL ARTERITIS
}

\author{
BY
}

\author{
GEORGE BENNETT
}

\begin{abstract}
Sunderland
THERE is ample evidence in the literature, collated and summarized by Roux (1954) and Bonnet (1954), that cortisone and ACTH are, generally speaking, effective in reducing the duration and intensity of the disease process in temporal arteritis. This has now been proved by serial biopsy (Harrison, Harrison, and Kopelman, 1955), though early reports were inconclusive in this respect. It has been suggested that this treatment also inhibits further extension of the lesions, implying that continued therapy is essential pending the natural termination of the process or alternatively of the life of its victim.
\end{abstract}

Although the manifestations of this disease are protean and sometimes fatal, visual loss is by far the commonest of those causing disablement, occurring in as many as 44 per cent. of cases (Roux, 1954) and being frequently total in degree; 15 per cent. of patients are said by Bruce (1949) to become virtually blind, and 26 per cent. by Whitfield, Cook, Evans, and Rudd (1953). Bonnet (1954) concluded that 50 per cent. of cases have ocular complications, and that 25 per cent. lose all useful vision. We should therefore rate the efficacy of any line of treatment primarily on its value in combating and restoring visual loss.

We must first, in any investigation into the effects of any drug on any disease, consider the behaviour of cases which have not had the benefit of such treatment. It is surprising to find that this simple precaution is frequently not observed in medical writings. On examining the relevant literature, we find that not all the cases annotated are, for various reasons, suitable for abstraction and analysis, but the following articles are worthy of mention. Parsons-Smith (1952) observed definite slight improvement in seven eyes, none in eleven eyes, and uncertain results in other eyes in cases of temporal arteritis showing visual loss. Kendall (1953) found slight improvement in only one eye out of ten affected. Bruce (1949) in his analysis noted only two cases with reasonable visual recovery out of 34 . Meadows (1954) described twelve patients with varying degrees of blindness in both eyes; only one eye out of the 24 showed any recovery. Thus we may expect some degree of recovery in a percentage of cases varying from 
5 to 30 in different series. If we sum the cases of Parsons-Smith, Kendall, and Meadows, we find that nine eyes out of 52 (17.3 per cent.) showed improvement.

We may now consider what hormonal therapy has to offer, in the face of the above figures, for this affliction. Opinions so far expressed are indefinite and often contradictory, and leave us without any firm or final decision. Franceschetti, in the discussion of a paper by Witmer (1951), forthrightly declaims against this form of therapy. Siegert (1952) considers it to be of rather doubtful value. Whitfield and others (1953) think that cortisone controls the disease to some extent but that relapse will occur on withdrawal. Chapin and Frost (1953) believe its value to be chiefly in prophylaxis. Meadows (1954) is rather dubious about its usefulness, although Evans (1954) comments on his favourable impressions as regards its therapeutic and prophylactic value. Roux (1954) agrees with the earlier British authors but would like more evidence on which to base a definite opinion. On the other hand, Bonnet (1954) considers hormonal therapy to be useless from every point of view, and is supported in this conclusion by Krysta (1953). A synopsis of abstractable published cases treated by cortisone or ACTH is given in Table I (overleaf). The column-headings are selfexplanatory, except the last column labelled "Type". This refers to the clinical localization of the lesion to either the retinal artery in the fundus ("retinal artery block") or to the nutrient vessels of the optic nerve ("neuritic"), as first described by Wagener (1946).

Table I indicates that in twenty cases cited only nine eyes showed definite improvement out of the seventeen positively affected; the improvement could only be described as very slight in four of these. In only three eyes was recovery useful and subtotal. Improvement did not occur in the few cases which showed obstruction of the central retinal artery. Of the cases which improved, the delay before treatment was instituted varied from 0 to 10 days. Among those which deteriorated, however, delays of only one day and 4 days are to be noted. In three patients, failure of vision in one eye commenced while treatment was being given for affection of the other eye.

To the above the author now adds a further six cases treated with cortisone. These are summarized in Table II (overleaf).

Five of the author's patients were females, and one male. Their ages varied between 73 and 82 years. In three cases both eyes were affected and in three (Cases 1, 5, and 6) only one (the reduced vision in the left eye of Case 5 was due to macular degenerative changes). The usual treatment schedule given was $150 \mathrm{mg}$. cortisone in divided doses daily for one week, then $100 \mathrm{mg}$. daily for one week, then $50 \mathrm{mg}$. daily for one week, and finally a maintenance dose of $25 \mathrm{mg}$. daily for a variable period; this dosage was exceeded in two cases. Delay before treatment commenced varied from one to 28 days. Ancillary forms of treatment with vasodilators were utilized 
TABLE I

PUBLISHED CASES OF TEMPORAL ARTERITIS WITH VISUAL LOSS TREATED WITH CORTISONE OR ACTH

\begin{tabular}{|c|c|c|c|c|c|c|c|c|c|}
\hline \multirow{3}{*}{ Author } & \multirow{3}{*}{ Date } & \multirow{3}{*}{$\begin{array}{l}\text { Case } \\
\text { No. }\end{array}$} & \multicolumn{4}{|c|}{ Visual Acuity } & \multirow{2}{*}{\multicolumn{2}{|c|}{$\begin{array}{l}\text { Period of Delay } \\
\text { before Treat- } \\
\text { ment (days) }\end{array}$}} & \multirow{3}{*}{ Type } \\
\hline & & & \multicolumn{2}{|c|}{$\begin{array}{l}\text { Before Treat- } \\
\text { ment or Worst }\end{array}$} & \multicolumn{2}{|c|}{ Final } & & & \\
\hline & & & Right & Left & Right & Left & Right & Left & \\
\hline Chavany and Taptas & 1948 & 1 & \multicolumn{4}{|c|}{ Improved with treatment } & - & - & - \\
\hline $\begin{array}{l}\text { Doret, Roux, and } \\
\text { Rywlin }\end{array}$ & 1951 & 2 & Nil & $6 / 6$ & Nil & $6 / 12$ & $?$ & Nil & - \\
\hline Fabian & 1952 & 3 & $\begin{array}{l}\text { C.F. } \\
40 \mathrm{~cm} \text {. }\end{array}$ & $6 / 6$ & $\begin{array}{l}\text { C.F. } \\
30 \mathrm{~cm} \text {. }\end{array}$ & $\begin{array}{l}\text { Less } \\
\text { than } \\
6 / 60\end{array}$ & - & - & $\begin{array}{l}\text { Retinal } \\
\text { Artery } \\
\text { Block }\end{array}$ \\
\hline Höök and Jernelius & 1952 & 4 & Nil & $6 / 6$ & Nil & $6 / 6$ & Some & - & Neuritic \\
\hline $\begin{array}{l}\text { Whitfield, Cooke, } \\
\text { Evans, and Rudd }\end{array}$ & 1953 & $\begin{array}{r}5 \\
6 \\
7 \\
8 \\
9 \\
10 \\
11 \\
12 \\
13\end{array}$ & \begin{tabular}{|c|} 
H.M. \\
Nil \\
Nil \\
Nil \\
Nil \\
P.L. \\
C.F. \\
6/24 \\
P.L.
\end{tabular} & $\begin{array}{l}\text { 6/12 } \\
\text { Nil } \\
\text { Nil } \\
\text { Nil } \\
\text { Nil } \\
6 / 9 \text { pt } \\
\text { C.F. } \\
\text { C.F. } \\
\text { 6/18 }\end{array}$ & $\begin{array}{c}6 / 60 \\
\text { Nil } \\
\text { Nil } \\
\text { Nil } \\
\text { Nil } \\
6 / 60 \\
6 / 6 \\
? \\
?\end{array}$ & $\begin{array}{c}6 / 12 \\
\text { Nil } \\
\text { Nil } \\
\text { Nil } \\
\text { Nil } \\
6 / 9 \\
6 / 18 \\
? \\
?\end{array}$ & \begin{tabular}{|c|} 
Few \\
22 \\
9 \\
24 \\
6 \\
7 \\
None \\
3 to 4 \\
9 months
\end{tabular} & \begin{tabular}{|c|} 
Few \\
18 \\
6 \\
28 \\
4 \\
10 \\
None \\
3 to 4 \\
7
\end{tabular} & $\begin{array}{c}- \\
\bar{Z} \\
\text { Neuritic } \\
\text { Neuritic } \\
? \\
\text { Neuritic } \\
\text { Neuritic } \\
\text { Neuritic } \\
?\end{array}$ \\
\hline Meadows & 1954 & $\begin{array}{l}14 \\
15 \\
16\end{array}$ & $\begin{array}{l}\text { P.L. } \\
\text { Deter } \\
\text { Unch }\end{array}$ & $\begin{array}{l}\text { Nil } \\
\text { orated } \mathrm{w} \\
\text { anged } \mathrm{w}\end{array}$ & $\begin{array}{l}\text { C.F. } \\
\text { ith treat } \\
\text { th treat }\end{array}$ & $\begin{array}{c}\text { Nil } \\
\text { tment } \\
\text { ment }\end{array}$ & None & None & - \\
\hline Roux & 1954 & 17 & Nil & $0 \cdot 2$ & Nil & $0 \cdot 7$ & 1 & None & Neuritic \\
\hline Krysta & 1954 & 18 & Nil & $2 / 25$ & P.L. & $2 / 25$ & Some & Some & Neuritic \\
\hline $\begin{array}{l}\text { Anderson and } \\
\text { Vallotton }\end{array}$ & 1955 & $\begin{array}{l}19 \\
20\end{array}$ & $\begin{array}{l}\text { Unc } \\
\text { Unc }\end{array}$ & $\begin{array}{l}\text { ged } w i \\
\text { ged wi }\end{array}$ & $\begin{array}{l}\text { th treati } \\
\text { th treatr }\end{array}$ & $\begin{array}{l}\text { ment } \\
\text { ment }\end{array}$ & - & - & $\begin{array}{l}\text { Retinal } \\
\text { Artery } \\
\text { Block }\end{array}$ \\
\hline
\end{tabular}

in all cases and in addition anticoagulants were prescribed in Case 4 and systemic aureomycin in Case 5. A central retinal artery block was present $\bigcirc$ in one of the eyes showing some recovery (Case 3). Whereas pain was relieved dramatically in all cases, the effect on vision can generally be said to be trivial. Thus, of the nine eyes showing visual loss, only three enjoyed $N$ some improvement, and in no case did this reach the level of $6 / 60$.

If we now add our nine eyes to those collected from the literature, we find some recovery in twelve eyes out of a total of 26 affected ( $46 \cdot 2$ per cent.). If we compare this with the proportional recovery in the cases described above in which cortisone was not given, we shall find a significant difference obtains $\left(X^{2}=5.94 ; n=1 ; P=\cdot 01-\cdot 02\right)$. This indicates that the better prognosis in the treated cases is a real difference and not a chance finding. 
TABLE II

AUTHOR'S SIX CASES OF TEMPORAL ARTERITIS WITH VISUAL LOSS TREATED WITH CORTISONE

\begin{tabular}{|c|c|c|c|c|c|c|c|}
\hline \multirow{3}{*}{ Case No. } & \multicolumn{4}{|c|}{ Visual Acuity } & \multirow{2}{*}{\multicolumn{2}{|c|}{$\begin{array}{c}\text { Length of Delay } \\
\text { before Treat- } \\
\text { ment (days) }\end{array}$}} & \multirow{3}{*}{ Type } \\
\hline & \multicolumn{2}{|c|}{$\begin{array}{c}\text { Before } \\
\text { Treatment }\end{array}$} & \multicolumn{2}{|c|}{ Final } & & & \\
\hline & Right & Left & Right & Left & Right & Left & \\
\hline 1 & $?$ & Nil & $6 / 12$ & Nil & - & 7 & Neuritic \\
\hline 2 & C.F. & Nil & C.F. & Nil & 2 & 28 & $\begin{array}{l}\text { Retinal Artery } \\
\text { Block }\end{array}$ \\
\hline 3 & H.M. & Nil & C.F. & Nil & 3 & 7 & $\begin{array}{l}\text { Retinal Artery } \\
\text { Block }\end{array}$ \\
\hline 4 & $6 / 60$ & C.F. & H.M. & $1 / 18$ & 1 & 7 & Neuritic \\
\hline 5 & Nil & P.L. & Nil & $6 / 60$ & 4 & - & Neuritic \\
\hline 6 & Nil & $6 / 9$ & H.M. & $6 / 6$ & 5 & - & Neuritic \\
\hline
\end{tabular}

\section{Summary}

The incidence and degree of visual loss in temporal arteritis is reviewed. The effect of cortisone or ACTH on such cases is considered and six personal cases so treated are described. Analysis indicates a significantly better prognosis under this therapy; the final visual standard attained, though often very low, is undoubtedly preferable to complete blindness.

I am indebted to the surgeons of the Southampton Eye Infirmary for their kindness in giving me access to their patients and records and encouragement in making this study.

\section{REFERENCES}

Anderson, B., and Vallotton, W. (1955). A.M.A. Arch. Ophthal., 54, 6.

BONNET, P. (1954). Arch. ophtal., 14, 24.

Bruce, G. M. (1949). Trans. Amer. ophthal. Soc., 47, 300.

Chapin, M. A., and Frost, R. A. (1953). J. Maine med. Ass., 44, 304.

Chavany, J. A., and Taptas, J. N. (1948). Presse méd., 56, 835.

Doret, J. P., Roux, J. L., and Rywlin, A. (1951). Schweiz. med. Wschr., 81, 946.

Evans, P. JAMESON (1954). Trans. ophthal. Soc. U.K., 74, 37.

Fabian, G. (1952). Klin. Mbl. Augenheilk., 121, 80.

Harrison, R. J., Harrison, C. V., and Kopelman, H. (1955). Brit. med. J., $2,1593$.

Höök, O., and Jernelius, B. (1952). Nord. Med., 48, 1224.

KENDALl, D. (1953). Brit. med. J., 2, 418.

KrySTA, F. (1953). Klin. Mbl. Augenheilk., 122, 739.

Meadows, S. P. (1954). Trans. ophthal. Soc. U.K., 74, 13.

PARSONS-SMITH, G. (1952). British Journal of Ophthalmology, 36, 615.

Roux, J. L. (1954). Helv. med. acta, Suppl. 34.

Siegert, P. (1952). Klin. Mbl. Augenheilk., 120, 254.

WAGENER, H. P. (1946). Amer. J. med. Sci., 212, 225

Whitfield, A. G. W., Cooke, W. T., Evans, P. Jameson, and Rudd, C. (1953). Lancet, $1,408$.

WITMER, R. (1951). Oph'halmologica (Basel), 121, 160. 